\title{
Obituari Setiya Utari (25 Juli 1967 - 08 Juni 2020)
}

Adib Rifqi Setiawan

\author{
"Jangan jadi orang biasa. Dengan menjadi orang luar biasa, sejarah akan \\ mencatat kita. Selain untuk diri sendiri, kita harus bisa jadikan orang lain \\ luar biasa." \\ - Setiya Utari pada 4 Oktober 2012 di Laboaratorium Fisika Lanjutan I \\ UPI
}

Siang hari pada 8 Juni 2020 saya dikagetkan oleh kabar bahwa Setiya Utari (Buk Ut) telah berpindah alam. Kabar tersebut saya peroleh kali pertama dari Dini Fitriani melalui telepon pukul 12.06, yang langsung saya konfirmasi kepada Muhammad Gina Nugraha (Pak Gin Gin) 2 menit kemudian. Lebih lanjut Pak Gin Gin meneruskan pesan teks WhatsApp terakhir yang dikirim melalui kontak Buk Ut ke grup Fisika UPI pada 8 Juni 2020 pulul 05.20:

Assalamualaikum... Wrwb...

Aku mencintai alam semesta dengan segala isinya....

Sehat dan bahagia selalu ... Aamiin

Alfatihah....

Ketika saya periksa kontak Buk Utari, tertulis bahwa terakhir dilihat pada hari itu pukul 05.36 .

Mestinya kabar tersebut saya terima lebih cepat, andai telepon Dini pukul 11.40 langsung saya jawab. Malah agak lebih cepat andai Pak Gin Gin tidak mengirim pesan secara broadcast, seiring perubahan kontak ponsel saya. Namun, yang jelas kabar tersebut benar. Buk Ut yang hadir ke Bumi pada Selasa Pon, 17 Robīul Akhīr 1387 H. / 25 Juli 1967 M. berpindah alam pada Senin Kliwon, 16 Syawwāl 1441 H. / 8 Juni 2020 M. dalam usia 52 tahun 318 hari - yang nyaris sama dengan usia Abū Ḥāmid Muḥammad ibn Muḥammad alĠozzālīy ketika pindah alam.

Pada malam hari sebelum Buk Ut berpindah alam, ialah 7 Juni 2020, nama beliau masih saya sebut dalam percakapan dengan wife in the making Wahyu Eka Saputri dan Fatimah 
Afifatuttohiroh yang meminta saran terkait proposal skripsi. Wajar kalau kedua orang tersebut turut kaget setelah menerima kabar Buk Ut berpindah alam.

Dulu Buk Ut kerap meminta saya agar dalam merencanakan riset, harus sudah bisa menyebutkan secara rapi dan rinci: (1) tujuan riset; (2) data yang dibutuhkan; (3) instrumen yang dapat digunakan; serta (4) metode yang bisa dipilih. Keempat hal ini yang biasa saya sampaikan sekaligus "menghidupkan" nama Buk Ut dalam obrolan dengan beberapa rekan saya terkait riset.

Nama Buk Ut memang sering saya sebut karena beliau merupakan satu dari tiga orang guru utama yang membangun pondasi perspektif saya secara utuh dan menyeluruh. Peran Buk Ut bagi saya laiknya al-Sayyidah Nafisah bint Amīr al-Ḥasaniyyah bagi Muhammad ibn Idrīs al-Syāfi'i. Letak perumpaan ialah status sex yang sama-sama perempuan serta menjadi orang paling berpengaruh yang dijumpai di urutan ketiga. Kita tahu semua bahwa perjumpaan al-Sayyidah Nafisah bint Amīr al-Ḥasaniyyah dan Muḥammad ibn Idrīs al-Syāfi'̄ di Kairo terjadi setelah founder madzhab Syāfi'î tersebut telah menerima pendidikan dari Mālik ibn Anas al-Aṣbaḥīy di Madinah dan Muḥammad ibn al-Ḥasan al-Syaybānī di Wāsiṭ.

Sejak meninggalkan Departemen Pendidikan Fisika Universitas Pendidikan Indonesia (UPI) pada 21 April 2017 silam, saya masih rutin menjumpai Buk Ut setiap tahun. Tahun 2018 kami berjumpa 2 kali, pada 8 Juli ketika masa libur akhir tahun pembelajaran di madrasah serta 24 November ketika pelaksanaan Seminar Nasional Fisika ke-4 (SiNaFi IV). Tahun 2019 lalu kami juga berjumpa ketika pelaksanaan SiNaFi 5.0 pada 23 November 2020. Percakapan yang kami alami dalam setiap perjumpaan turut membahas secara tuntas pembelajaran yang saya lakoni maupun keseharian yang kami jalani.

Salah satu percakapan terbaik dengan Buk Ut ketika saya sudah meninggalkan UPI ialah saat kami membahas kelanjutan pendidikan formal pada 8 Juli 2018. Pada waktu itu saya menceritakan bahwa untuk saat ini tidak melanjutkan pendidikan formal ke jenjang S2 karena alasan niat. Buk Ut kemudian menyarankan agar saya tetap serius dengan pembelajaran yang dilakoni di madrasah dan pondok pesantren serta tak ragu menceritakan kepada khalayak melalui jurnal akademik maupun paper konferensi.

Ungkapan paling mengejutkan ialah ketika Buk Ut mengungkap "garansi" bahwa kalau saran tersebut dilakukan tak sampai 2 tahun saya akan matang dalam memandu pembelajaran 
serta memiliki publikasi sebanyak 10 jurnal. Meski ketika menyimak "garansi" itu nyaris tak percaya, tapi saran bernada tantangan yang membangkitkan angan itu juga terasa asik andai dapat terwujud menjadi kenangan. Beruntung sebelum Buk Ut pindah alam, saya sudah bisa mengikuti step by step saran tersebut. Beruntung pula publikasi sebanyak 10 jurnal sudah dapat mewujud pada 21 April 2020 ketika Edukatif yang dikelola oleh Fadhilaturrahmi menerbitkan artikel saya.

Kini ketika Buk Ut tak lagi bisa disapa melalui WhatsApp maupun diajak mengobrol ketika saya main ke Bandung, saya hanya bisa berharap agar beliau senantiasa mendapat riḍō Allōh subḥānahu wa ta'ālā sekaligus bersyukur memiliki pengalalan dididik secara langsung oleh beliau yang menjadi pembimbing akademik, pengajar dalam perkuliahan, pembimbing sekaligus penguji skripsi, maupun pembimbing riset literasi saintifik setelah kuliah S1.

Debut pertemuan saya dengan Buk Utari terjadi pada 10 Agustus 2012 ketika saya ikut acara buka bersama para punggawa Departemen Pendidikan Fisika UPI. Saya ikut bersama Sherly Yulidarti, Uwais Al Qorni Akbar, Adi Lukman Ghofur, Maryam Musfiroh, dan Lailul Munjidah setelah diajak oleh Pak Agus Jauhari. Harusnya debut pertemuan kami lebih awal karena beliau memiliki jadwal mengisi matrikulasi. Sayang saat itu beliau sedang berhalangan.

Dalam debut pertemuan tersebut, Buk Utari mengungkap tuturan yang membuat saya ingin segera membuktikan.

"Tak ada dosen di UPI yang lebih ramah pada mahasiswanya selain di

Fisika," ungkap beliau yang memfoto saya bersama Pak Agus Jauhari.

"Iya tah Buk?" tanya saya sembari menunjukkan raut wajah penasaran.

"Coba cari saja," begitu jawab beliau.

Belakangan saya membuktikan bahwa ungkapan Buk Utari memang tepat. Dosen di Pendidikan Fisika memang ramah dan profesional. Mereka bisa terlibat interaksi intim dengan tetap semadyana (objective) dalam bekerja.

Dosen di Pendidikan Fisika bisa hebat sebagai individu dan sebagai bagian tim yang padu. Suasana yang dibangun sejak lama terus bisa dilantan dalam waktu panjang. Suasana hangat seperti ini bisa memberikan kenyamanan sendiri bagi orang yang baru bergabung, entah sebagai pengajar, staf, maupun pelajar di sini. Tidak mudah membangun suasana interaksi intim yang sama-sama memahami batasan dalam kebersamaan. 
Buk Utari dan saya bertemu lagi untuk keempat kalinya pada 04 Oktober 2012 dalam acara kumpul PA (pembimbing akademik), kumpul perdana antara dosen PA dan anak asuhnya. Pertemuan ini terjadi setelah beberapa hari sebelumnya saya 'memperkenalkan' diri sebagai anak asuh. Oleh Buk Utari, saya diminta untuk mengumpulkan rekan satu PA dan segera mengadakan pertemuan perdana sebagai ajang perkenalan. Urutan keempat terjadi karena Buk Ut sebelumnya menjadi pengisi acara ketika masa orientasi kampus (MoKa) yang menjadi pertemuan kedua kami, serta pertemuan ketiga terjadi pada saat saya 'memperkenalkan' diri.

Pada masa itu, hanya Buk Utari selaku dosen PA untuk angkatan saya, yang mengadakan pertemuan ini. Hal ini berdampak sangat bagus bagi perjalanan kami-anak asuh beliauselama perkuliahan. Buk Utari memiliki sederet kesibukan yang memaksa tak selalu bisa bertemu anak asuhnya setiap saat. Pertemuan perdana PA ini juga menjadi ajang pemberian sederet pesan dari Buk Utari kepada anak asuh beliau*).

\begin{abstract}
"Kita harus bersyukur telah diberi kesempatan menimba ilmu di UPI, terutama yang mendapatkan beasiswa. Untuk itu, sebagai bukti dari rasa bersyukur itu, kita harus bekerja keras, memanfaatkan yang ada untuk mengeruk ilmu yang ada di UPI ini. Tak boleh malas. Dengan begitu, kesempatan yang didapatkan tak terbuang sia-sia." ungkap beliau dalam membuka sederet pesan tersebut. ${ }^{*}$
\end{abstract}

Salah satu pesan yang diisampaikan pada 04 Oktober 2012 di Laboaratorium Fisika Lanjutan I dalam acara kumpul perdana dengan anak asuh akademik tersebut bisa mengakar meski dirasa sebagai klise yang diafdruk berulang. Mungkin karena diberikan dari hati oleh orang yang sudah membiasakan bersikap seperti itu, jadi bisa sampai ke hati penerimanya dan mengendap.

Dalam pertemuan perdana PA itu, Buk Ut langsung tampil keras dan agresif. Beliau, yang juga menjadi ketua program studi Pendidikan Fisika, berkata kepada anak asuhnya apa yang dituntut departemen dari kami. Itu awal yang bagus. Salah satu bagian utama dalam hubungan guru dan siswa adalah bahwa guru harus membuat siswa bertanggung jawab atas tindakannya, kesalahannya, tingkat penampilan, dan hasilnya. Kita semua ada pada 
zaman yang mementingkan hasil. Hasil yang maksimal dan konsisten bisa diperoleh melalui proses yang dibiasakan.

Di luar urusan akademik, Buk Utari adalah sosok yang tenang. Beliau rajin menyapa dan kami bisa mengobrol mengenai banyak hal. Beliau orang yang ramah. Tetapi, kalau sudah menyangkut urusan akademik—pada masa-masa perkuliahan—beliau jauh berbeda. Saya selalu dapat mengerti posisi Buk Utari. Saya dapat mengerti perubahan drastis pada diri beliau begitu "kick off" kuliah dimulai. Sebagai pendidik, beliau ingin semua murid tidak menjadi orang biasa. Terlebih bagi saya yang notabene menjadi anak asuh beliau.

Buk Utari tidak akan membuat murid beliau bersantai-santai. Beliau akan memarahi kami kalau prestasi kami turun. Beliau selalu ingin murid beliau tampil maksimal dengan terus menjaga semangat kemauan. Ketika kemauan sudah ada, pasti hasilnya maksimal. Kalau tidak maksimal, kemauan belum ada atau kalau diklaim sudah ada hanya nonsense.

Ketika berbicara dengan saya yang prestasinya tak sesuai harapan, boleh jadi beliau berkata: "Itu tadi sampah," tapi beliau melanjutkan dengan, "untuk ukuran orang seperti kamu." Lanjutannya ini berfungsi untuk membantu saya bangun sesudah pukulan awal. Teguran, lalu diimbangi dengan sanjungan. "Kenapa kamu berbuat seperti itu? Kamu bisa lebih baik."

Buk Utari rajin mengembangkan penguasaan terhadap bidangnya. Tidak common sense jika murid diberi kesempatan berkata kepada diri sendiri, "Guru tidak mengerti apa yang saya katakan." Jika murid kehilangan kepercayaan kepada pengetahuan gurunya, mereka pun akan kehilangan kepercayaan kepada guru. Penguasaan terhadap bidang yang digeluti harus selalu dijaga dan dikembangkan sepanjang waktu.

Dari sudut pandang saya, Buk Utari orang yang konsisten menjaga tujuan awal kami di Pendidikan Fisika: kuliah. Beliau tidak pernah melarang murid beliau mencari minat di luar. Ketika masih kuliah dulu beliau juga aktif di organisasi himpunan. Namun, tak ada keraguan bahwa kewajiban kami adalah kuliah.

Kita boleh saja memiliki minat di luar: saya suka menonton 2NE1, Josua Timotius Manik aktif di organisasi dan ngobrolin Manchester United, satu dua teman saya suka aktif dalam kegiatan pengembangan bakat. Namun, jangan sampai minat di luar itu mengganggu kuliah 
kita. Tujuan utama, yang juga menjadi kewajiban saya di Pendidikan Fisika adalah kuliah. Mau tidak mau harus saya jalani semaksimal mungkin. Untuk minat di luar, sifatnya hanya ke-sunnah-an saja, boleh ditanggalkan terutama ketika sudah menghambat kewajiban.

Buk Utari memang seorang dengan energi, keberanian, dan darah yang panas, dengan naluri tajam pada pendidikan ilmu alam dan strateginya. Beliau menjadi orang yang banyak berpengaruh kepada saya sejak kami memulai kebersamaan kami. Buk Utari mengambil alih banyak tanggung jawab untuk memastikan bahwa diri saya tetap penuh semangat. Saya tidak bisa mengesampingkan bantuan semacam itu dari beliau.

Saya butuh kepercayaan diri, sedikit keberanian. Buk Utari tak pernah takut apapun, beliau orang yang perkasa. Beliau bisa diajak memandang beragam sisi permasalahan. Beliau tidak hanya mempertimbangkan dirinya, tetapi juga ada yang lain. Dan itu bagus untuk saya. Contoh bagusnya adalah ketika beliau memberikan buku teks standar tentang fisika untuk perguruan tinggi.

Ada banyak buku standar yang ditawarkan, tapi kalau kepada saya Buk Utari lebih menyarankan buku fisika yang ditulis Douglas C. Giancoli. Meski saya lebih sering melihat Buk Utari memakai buku fisika yang ditulis oleh Paul A. Tipler. Buk Ut juga yang menyarankan kepada saya agar memakai buku metode riset dari Jack R. Fraenkel, meski beliau lebih kerap tampak memakai John W. Creswell.

Menguasai satu buku standar adalah langkah awal dalam belajar. Semua buku fisika isinya sama saja, yang beda adalah pendekatannya. Buku yang ditulis Douglas C. menggunakan pendekatan konseptual yang cenderung memakai operasi matematika sederhana. Saya nyaman menggunakan buku ini. Buku yang ditulis Jack R. Fraenkel juga menggunakan bahasa yang sederhana dan tampilannya nyaman dibaca. Pendekatan, bahasa, dan tampilan yang tak cocok sering berdampak pada rasa bosan yang muncul. Dan Buk Utari senantiasa menghindari tiga perkara ini, yang membuat pertemuan dengan beliau tak pernah membosankan. Apalagi pola tanda tangan kami memiliki kemiripan.

*) Pesan dari Bu Utari saat kumpul perdana PA adalah:

\section{[1] Bersyukur}


Kita harus bersyukur telah diberi kesempatan menimba ilmu di UPI, terutama yang mendapatkan beasiswa. Untuk itu, sebagai bukti dari rasa bersyukur itu, kita harus bekerja keras, memanfaatkan yang ada untuk mengeruk ilmu yang ada di UPI ini. Tak boleh malas. Dengan begitu, kesempatan yang didapatkan tak terbuang sia-sia.

\section{[2] Kuasai Konsep-Konsep Fisika dan Bahasa Inggris}

Dua hal ini tak bisa ditawar lagi. Ini sudah batas minimal yang harus kita kuasai. Menguasai konsep-konsep Fisika, berarti harus bisa menghubungkan segala yang ada di dunia ini dengan konsep-konsep Fisika. Selain itu, untuk dapat berkomunikasi dengan baik, harus menguasai Bahasa Inggris. Karena bahasa itu adalah bahasa internasional.

\section{[3] Siap Menerima Kesempatan Mendadak}

Terkadang kesempatan bagus datang mendadak. Mau tak mau kita harus menerimanya dan mampu memanfaatkannya. Mungkin kesempatan yang sama tidak akan kita temui lagi.

\section{[4] Gizi Bagus dan Istirahat Cukup}

Dengan gizi yang bagus, selain tubuh sehat, pikiran juga OK. Tak usah mahal-mahal, yang penting kebutuhan gizi terpenuhi. Istirahatpun demikian. Istirahat cukup bukan berarti banyak tidur. Tidur maksimal 3 jam sehari. Biarpun sedikit, namun asal efektif, pasti istirahat tetap cukup.

\section{[5] Posisikan Diri Sebagai Pemangku Kebijakan}

Dengan ini, kita bisa menjalankan kebijakan sesuai keinginan kita. Tentunya tetap bertanggung jawab. Untuk itu, kita harus membuat orang lain percaya pada kita dan kita harus bisa dipercaya serta bisa bekerja sama dalam tim.

\section{[6] Harus Aktif}

Tak boleh malu jika belum tahu. Apapun yang terjadi, kita harus bisa 
tahu, tak boleh tidak.

\section{[7] Belajar Untuk Mengabdi}

Kita harus selalu bisa mengabdi, baik untuk agama, negara, maupun masyarakat. Ujung-ujungnya persembahkan yang kita lakukan dan usahakan pada Tuhan.

\section{[8] Profesional}

Di mana saja dan kapan saja kita harus profesional. Tak boleh subjektif, harus objektif. Dengan begini, di manapun kita berada kita akan melakukannya semaksimal mungkin, minimal sesuai target.

\section{[9] IPK Minimal 3,4}

Selain dengan belajar, harus sering konsultasi dengan dosen dan pakar. Buku text yang disarankan juga harus punya sendiri. Untuk masalah buku, jangan pelit. Anggaran untuk buku tak terbatas. Selama masih punya uang buku harus punya.

\section{[10] Jangan Jadi Orang Biasa}

Dengan menjadi orang luar biasa, sejarah akan mencatat kita. Selain untuk diri sendiri, kita harus bisa jadikan orang lain luar biasa.

K.Rb.Pa.181041.100620.00:44

Artikel ini diterbitkan melalui blog pribadi pada 10 Juni 2020 pukul 00.53 dengan judul Obituari Setiya Utari (25 Juli 1967 - 08 Juni 2020) 